\title{
PENGGUNAAN MEDIA KOMIK DALAM PEMBELAJARAN IPA UNTUK MENINGKATKAN MOTIVASI DAN HASIL BELAJAR KOGNITIF DAN AFEKTIF
}

\author{
Retno Puspitorini, A.K. Prodjosantoso, Bambang Subali, dan Jumadi \\ Fakultas Matematika dan IImu Pengetahuan Alam Universitas Negeri Yogyakarta \\ email: retnpushpito@yahoo.co.id
}

\begin{abstract}
Abstrak: Penelitian ini bertujuan untuk mendeskripsikan peningkatan motivasi, hasil belajar kognitif, hasil belajar afektif peserta didik dalam pembelajaran IPA dengan menggunakan media komik. Penelitian dilakukan lewat quasi experiment dengan desain one group pretest-posttest. Subjek penelitian adalah 57 peserta didik kelas VII SMPN 1 Banjarnegara. Media komik digunakan dalam pembelajaran IPA selama 6 kali tatap muka. Data motivasi dan hasil belajar afektif diperoleh lewat angket dan observasi, sedangkan hasil belajar kognitif lewat pretes dan postes. Hasil penelitian menunjukkan bahwa penggunaan media komik di dalam pembelajaran IPA mampu meningkatkan motivasi belajar peserta didik dengan nilai gain skor sebesar 0,55 (sedang); hasil belajar ranah kognitif dengan gain skor sebesar 0,42 (sedang); dan meningkatkan hasil belajar ranah afektif dengan gain skor sebesar 0,34 (sedang). Hasil uji beda antara sebelum dan setelah perlakuan menunjukkan adanya perbedaan baik yang menyangkut motivasi belajar, hasil belajar ranah kognitif, maupun hasil belajar ranah afektif.
\end{abstract}

Kata Kunci: media komik, pembelajaran IPA, motivasi, hasil belajar kognititf, hasil belajar afektif

\section{THE USE OF COMIC MEDIA IN SCIENCE INSTRUCTION TO IMPROVE MOTIVATION AND COGNITIVE AND AFFECTIVE ACHIEVEMENT}

\begin{abstract}
This study was aimed to describe the improvement of students' motivation, cognitive and affective learning achievement in science instruction using comic media. The study was carried out using the quasi experiment with the one group pretest-posttest design. The subjects consisted of 57 seventh grade students of SMPN 1 Banjarnegara.Comic media were used in science instruction for six times. The data on motivation and affective learning achievement were obtained through questionnaires and observation, while the cognitive learning achievement was obtained through the pretest and posttest. The findings of the study showed that the use of the comic media in the science instruction could improve the students' motivation with a gain score of 0.55 ; improve the cognitive learning achievement with a gain score of 0.42 ; and improve the affective learning achievement with a gain score of 0.34. There was a significant difference in the students' motivation, cognitive learning achievement, and affective learning achievement before and after the treatment.
\end{abstract}

Keywords: comicmedia, Science instruction, motivation, cognitive achievement, affective achievement

\section{PENDAHULUAN}

Pendidikan memegang peranan penting dalam membentuk generasi penerus bangsa sebagaimana diamanatkan dalam Undang-Undang RI Nomor 20 Tahun 2003 tentang Sistem Pendidikan Nasional, Pasal 3 yang menyatakan bahwa pendidikan nasional berfungsi mengembangkan kemampuan dan membentuk watak serta peradaban bangsa yang bermartabat dalam rangka mencerdaskan kehidupan bangsa. Di dalam undang-undang tersebut, juga dikemukakan bahwa pendidikan nasional bertujuan untuk mengembangkan potensi peserta didik agar menjadi manusia yang beriman dan bertaqwa kepada Tuhan yang Maha Esa, berakhlak mulia, sehat, berilmu, cakap, kreatif, mandiri, dan menjadi warga negara yang demokratis serta bertanggung jawab.

Pencapaian tersebut didukung oleh pemerintah lewat kebijakan Nasional Pengembangan Karakter Bangsa Tahun 2010-2025. Tujuan dari pendidikan karakter bangsa adalah untuk membina dan mengembangkan karakter warga negara sesuai dengan dasar negara yaitu Pancasila (Zuchdi, 2011:32). Implikasi kebijakan tersebut adalah diintegrasikannya pendidikan 
karakter di setiap mata pelajaran, termasuk pembelajaran IPA. Suyanto (2011: 97) menjelaskan bahwa pendidikan karakter itu penting dan dibutuhkan untuk mencegah menurunnya nilai moral dan nilai sosial yang berdampak pada berbagai aspek.

Oleh karena itu, proses pendidikan dan kegiatan pembelajaran tidak lepas dari pembentukan moral. Kegiatan belajar akan tercapai ketika di dalam diri peserta didik telah terjadi perubahan pengetahuan dan perubahan tingkah laku. Pembelajaran tidak hanya mengedepankan perubahan pengetahuan melalui transfer of knowledge, tetapi juga bertanggung jawab dalam perubahan tingkah laku dengan adanya transfer of value.

Kurikulum memegang peranan yang sangat penting di dalam suatu proses pendidikan. Berdasarkan PP No.19 Tahun 2005 mengenai Standar Nasional Pendidikan, kurikulum sebagai seperangkat rencana dan pengaturan mengenai tujuan, isi, dan bahan pelajaran serta cara yang digunakan sebagai pedoman penyelenggaraan kegiatan pembelajaran untuk mencapai tujuan pendidikan. Proses pendidikan tidak dapat lepas dari kurikulum, bahkan pelaksanaan program pembelajaran di sekolah mengacu pada tujuan pendidikan yang telah diatur di dalam kurikulum. Sejak tahun 2013 pemerintah memberlakukan kurikulum baru yang dikenal dengan Kurikulum 2013.

Kemendikbud (2013:8) menjelaskan bahwa dalam Kurikulum 2013 setiap pembelajaran wajib mencakup empat kompetensi inti yang meliputi aspek sikap (keagamaan dan sosial), pengetahuan, dan keterampilan (penerapan pengetahuan). Oleh karena itu, penilaian di dalam kurikulum 2013 juga mencakup kompetensi sikap, pengetahuan, dan keterampilan.

IPA dikembangkan sebagai pelajaran integrative science bukan sebagai pendidikan disiplin ilmu. IPA berorientasi aplikatif, pengembangan kemampuan berpikir, kemampuan belajar, rasa ingin tahu, dan pengembangan sikap peduli, dan bertanggung jawab terhadap lingkungan sosial dan alam (Kemendikbud: 2013:45). Dengan kata lain, pembelajaran IPA mem- belajarkan pengetahuan, sikap, karakter, dan keterampilan yang diajarkan secara terpadu.

Pembelajaran IPA tidak lepas dari media dan bahan ajar yang digunakan. Akan tetapi, media dan bahan ajar yang beredar di lapangan belum sesuai dengan harapan pemerintah kaitannya dengan materi IPA terpadu. Selain itu, media dan bahan ajar yang umum dan sering digunakan berupa buku teks atau modul dengan ciri khas banyak berisi tulisan atau penjelasan dengan kalimat dan sedikit disertai gambar yang cenderung membuat peserta didik bosan dan kurang termotivasi, sebagaimana diungkapkan oleh Daryanto (2013:128) bahwa peserta didik cenderung tidak menyukai buku teks apalagi yang tidak disertai gambar dan ilustrasi yang menarik, dan secara empirik siswa cenderung menyukai buku bergambar, penuh dengan warna, dan divisualisasikan dalam bentuk realistis atau kartun.

Ditambah lagi dengan asumsi bahwa IPA merupakan pelajaran yang sulit dan penuh teori, pembelajaran yang membosankan dan dengan penggunaan media dan metode yang kurang inovatif, maka akan mengakibatkan peserta didik malas belajar IPA sehingga minat peserta didik terhadap IPA berkurang. Minat merupakan modal awal terbentuknya motivasi. Arigiyati (2011:923) menyatakan bahwa seseorang yang memiliki motivasi besar akan menampakkan minat, perhatian, konsentrasi penuh, ketekuanan tinggi, serta berorientasi pada prestasi tanpa mengenal perasaan bosan, jenuh, dan menyerah.

Oleh karena itu, jika minat peserta didik berkurang, maka motivasi peserta didik untuk belajar IPA juga berkurang sehingga akan berdampak pada hasil belajar. Hal tersebut disebabkan karena motivasi memberikan sumbangan terhadap hasil belajar sebagaimana hasil penelitian Hamdu (2011) menunjukkan bahwa motivasi belajar berpengaruh sebesar $48,1 \%$ terhadap prestasi belajar IPA. Hal tersebut didukung oleh hasil penelitian Yasa dkk (2013) bahwa peserta didik yang memiliki motivasi belajar tinggi akan lebih mudah mengikuti proses pembelajaran karena merasa pembelajaran itu penting, sebaliknya peserta didik dengan moti- 
vasi rendah terlihat tidak bergairah sehingga mengalami kesulitan memahami konsep dan proses pembelajaran tidak kondusif.

Salah satu upaya meningkatkan minat dan motivasi belajar peserta didik, yaitu digunakannya media pembelajaran yang menarik, contohnya komik. Sebagaimana dikatakan Sudjana \& Rivai (2011:68) bahwa peranan komik dalam pengajaran adalah kemampuannya dalam meningkatkan minat belajar para peserta didik. Nugraha (2013:61) menyatakan bahwa komik sains merupakan salah satu alternatif media bermain sambil belajar. Pemberian pengalaman belajar yang menyenangkan dapat meningkatkan hasil belajar peserta didik. Selain itu, penggunaan komik sains dalam pembelajaran membuat kegiatan pembelajaran lebih menarik dan tidak membosankan sehinggga minat belajar peserta didik menjadi lebih tinggi. Hasil penelitian Yasa, dkk. (2013) menunjukkan bahwa peserta didik yang belajar dengan menggunakan komik kearifan lokal Bali lebih unggul dalam hal motivasi belajar dan pemahaman konsep.

Tidak hanya itu, penelitian mengenai model pembelajaran berbasis komik oleh Wahyudi (2010) diperoleh hasil bahwa pencapaian ranah afektif dalam pembelajaran pendidikan kewargenegaraan dengan penerapan model pembelajaran berbasis komik pada anak berkesulitan belajar sangat signifikan di Kabupaten Sidoarjo, Mojokerto, dan Kota Surabaya. Daryanto (2013:27) mengatakan bahwa komik menyediakan cerita yang sederhana, mudah ditangkap dan dipahami isinya sehingga sangat digemari oleh anak-anak ataupun orang dewasa. Apabila media komik diintegrasikan dengan karakter melalui tokoh dan jalan cerita, maka peserta didik akan mendapatkan contoh dan suri teladan yang baik dan patut dicontoh, sehingga secara tidak langsung komik dapat menanamkan nilai, sikap, dan karakter. Selain itu peserta didik juga merasa tidak digurui.

Hal tersebut menunjukkan bahwa komik dapat memberikan dampak yang positif terhadap motivais, hasil belajar kognitif, dan afektif. Penelitian ini bertujuan untuk mengetahui deskripsi peningkatan: (1) motivasi; (2) hasil belajar kognitif; dan (3) hasil belajar afektif peserta didik dalam pembelajaran IPA dengan menggunakan media komik.

\section{METODE}

Penelitian ini dilakukan lewat pendekatan quasi experiment dengan menggunakan desain one group pretest-posttest yang diilustrasikan pada Gambar 1.

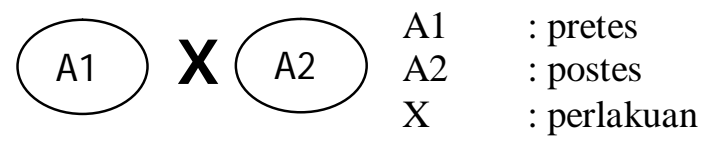

\section{Gambar 1. Desain Penelitian}

Subjek penelitian adalah 57 peserta didik kelas VII di SMP Negeri 1 Banjarnegara. Teknik dan instrumen pengumpulan data dalam penelitian ini bertujuan untuk medeskripsikan peningkatan motivasi, hasil belajar kognitif, dan hasil belajar afektif. Teknik dan instrumen pengumpulan data terangkum pada Tabel 1.

Jenis data berupa data kuantitatif yang berupa skor. Skor penilaian diubah menjadi nilai dalam skala 100 dengan persamaan:

Nilai Psikomotor $=\frac{\text { skor yang diperoleh siswa }}{\text { skor maksimal }} \times 100$

Tabel 1. Teknik dan Instrumen Pengumpulan Data

\begin{tabular}{llll}
\hline No. & Variabel & Teknik & Instrumen \\
\hline 1. & Motivasi & Angket & Lembar Angket \\
& & Observasi & Lembar Observasi \\
2. & Kognitif & Tes & Soal Pilihan Ganda \\
3. & Afektif & Angket & Lembar Angket \\
& & Observasi & Lembar Observasi \\
\hline
\end{tabular}


Besarnya peningkatan motivasi, hasil belajar kognitif, dan hasil belajar afektif dianalisis dengan menggunakan nilai Gain. Nilai awal dan nilai akhir digunakan untuk memeroleh Gain score melalui persamaan yang dikemukakan oleh Knight (2004:47):

$\mathrm{g}=\underline{\% \text { rata-rata posttest }-\% \text { rata-rata pretest }}$ $100-\%$ rata-rata pretest

Rata-rata yang dimaksud adalah rata-rata kelas. Rata-rata posttes motivasi dan hasil belajar afektif diasumsikan sebagai nilai ratarata angket setelah peserta didik menggunakan media komik dalam pembelajaran IPA, dan rata-rata pretes merupakan rata-rata nilai angket motivasi dan hasil belajar afektif sebelum peserta didik menggunakan media komik. Ratarata posttes kognitif merupakan nilai rata-rata hasil tes setelah peserta didik menggunakan media komik, dan rata-rata pretes kognititf merupakan nilai rata-rata tes sebelum peserta didik menggunakan media komik.

Nilai gain kemudian diklasifikasikan dengan kriteria gain skor. Kriteria gain skor menurut Hake (1998:65) disajikan pada Tabel 2.

Tabel 2. Kriteria Gain Skor

\begin{tabular}{ll}
\hline Kriteria & Nilai \\
\hline Tinggi & $\mathrm{g} \geq 0,7$ \\
Sedang & $0,7>\mathrm{g} \geq 0,3$ \\
Rendah & $\mathrm{g}<0,3$ \\
\hline
\end{tabular}

Analisis data juga dilakukan dengan menggunakan uji statistik, yaitu uji beda. Ada tidaknya perubahan motivasi, hasil belajar kognitif, dan hasil belajar afektif peserta didik yang signifikan akibat penggunaan media komik dalam pembelajaran IPA dapat ditentukan dengan menggunakan uji t. Pengujian dilakukan dengan t-tes untuk sampel dependen dengan hipotesis berikut.

$\mathrm{H}_{0}: \mathrm{m}_{1}=\mathrm{m}_{2}$ (tidak ada perbedaan antara sebelum dan setelah menggunakan media komik)

$\mathrm{H}_{\mathrm{a}}: \mathrm{m}_{1} \neq \mathrm{m}_{2}$ (ada perbedaan antara sebelum dan setelah menggunakan media komik)

$\alpha=0,05, \mathrm{H}$ ditolak jika $\mathrm{p}<0,05$ (Sulistyo, 2012:91).

\section{HASIL DAN PEMBAHASAN \\ Motivasi}

Peningkatan motivasi dapat dilihat dengan membandingkan data pengisian angket antara sebelum dan seteleh menggunakan media komik dalam proses pembelajaran IPA. Peningkatan motivasi belajar peserta didik diperoleh dengan cara mencari Gain Score. Hasil yang diperoleh menunjukkan bahwa peserta didik mengalami peningkatan motivasi. Peningkatan motivasi tersebut terlihat dengan besarnya nilai Gain Score yang diperoleh, yaitu sebesar 0,55 yang tergolong dalam kategori sedang.

Ada tidaknya perbedaan motivasi antara sebelum dan setelah menggunakan komik, dilakukan dengan menggunakan data angket. Pengujian dilakukan dengan t-tes untuk sampel dependen. Hasil pengujian menunjukkan bahwa nilai sig 0.000 yang berarti bahwa sig $<0.05(\alpha)$ maka $\mathrm{H}_{0}$ ditolak, yang berarti bahwa terdapat perbedaan motivasi yang signifikan antara sebelum dan setelah menggunakan komik.

Peserta didik merasa lebih termotivasi ketika pembelajaran menggunakan media komik. Hal ini juga didukung oleh hasil respon peserta didik yang menunjukkan bahwa adanya komik IPA membuat peserta didik lebih termotivasi dan senang untuk belajar. Dukungan komik terhadap motivasi juga dapat dilihat dari respon peserta didik bahwa komik IPA memberikan hiburan dan tidak membosankan dalam belajar IPA. Peserta didik menunjukkan antusias dan motivasi di dalam belajar sehingga dapat dikatakan komik IPA menunjang motivasi belajar.

Hal tersebut sesuai dengan hasil penelitian penggunaan media komik dalam pembelajaran sosiologi oleh Wardani (2012) yang menunjukkan bahwa peserta didik lebih senang jika pembelajaran dilakukan dengan menggunakan media komik daripada ceramah. Selain itu, hasil penelitian Yasa dkk (2013) juga menunjukkan bahwa peserta didik yang belajar dengan menggunakan komik berorientasi kearifan lokal Bali lebih unggul dalam motivasi belajar.

Observasi dilakukan selama proses pembelajaran dengan menggunakan komik IPA selama 6 pertemuan. Grafik rata-rata penilaian 
observasi setiap pertemuan ditunjukkan oleh Gambar 2.

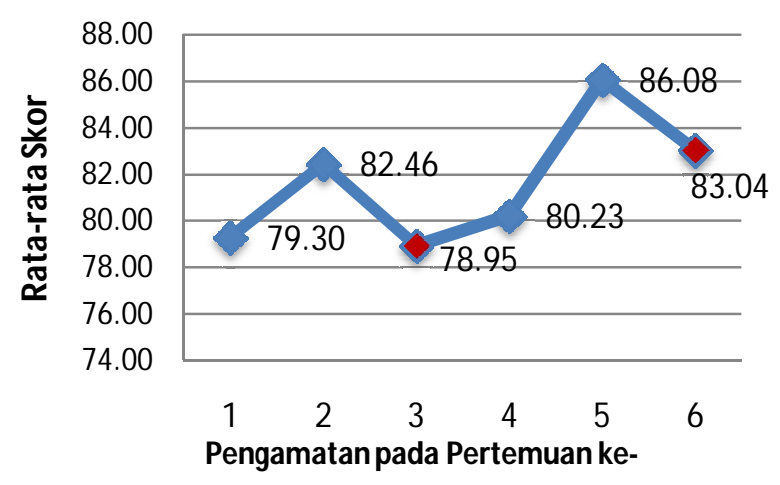

\section{Gambar 2. Rata-rata Penilaian Observasi Motivasi pada setiap Pertemuan}

Gambar grafik menunjukkan bahwa peningkatan motivasi belajar peserta didik terjadi pada pertemuan ke dua, ke empat, dan kelima. Pertemuan pertama, kedua, keempat, dan kelima diisi dengan aktivitas praktikum, sedangkan pertemuan ketiga dan keenam diisi dengan kegiatan tatap muka dan diskusi di dalam kelas. Berdasarkan kegiatan tersebut dapat diketahui bahwa peningkatan motivasi peserta didik paling baik ketika pada aktivitas praktikum.

Hal tersebut menunjukkan bahwa peserta didik yang belajar dengan menggunakan media komik, lebih termotivasi jika pembelajaran diisi dengan praktikum atau kegiatan laboratorium. Hal tersebut sesuai dengan penelitian yang dilakukan oleh Fajarianingtyas \& Hidayat yang menunjukkan bahwa ada pengaruh yang positif antara motivasi belajar mahasiswa dalam aktivitas praktikum IPA terhadap hasil belajar psikomotor dengan nilai korelasi sebesar 0,623. Sudjana \& Rivai (2011:68) mengatakan bahwa penggunaan komik di dalam pembelajaran akan lebih baik jika dipadu dengan metode mengajar sehingga komik akan dapat menjadi alat pembelajaran yang efektif. Dengan demikian, berdasarkan hasil penelitian dapat dikatakan bahwa perpaduan metode belajar eksperimen dengan aktivitas laboratorium lebih efektif untuk meningkatkan motivasi belajar perserta didik.

\section{Hasil Belajar Kogntif}

Peningkatan hasil belajar kognitif dapat dilihat dengan membandingkan nilai pretes dan postes. Peningkatan hasil belajar kognitif peserta didik diperoleh dengan cara mencari Gain Score. Hasil yang diperoleh menunjukkan bahwa peserta didik mengalami peningkatan hasil belajar kognitif yang terlihat dengan besarnya nilai Gain Score yang diperoleh, yaitu sebesar 0,42 yang tergolong dalam kategori sedang.

Berdasarkan perolehan nilai gain dapat disimpulkan bahwa media komik dapat meningkatkan pengetahuan peserta didik. Hal tersebut didukung oleh penelitian tentang pembuatan komik sains inkuiri oleh Nugraha (2012) yang menunjukkan peningkatan hasil belajar kognitif peserta didik berdasarkan uji gain. Hasil penelitian Mediawati (2011) tentang pembelajaran akuntansi melalui media komik menunjukkan terjadinya peningkatan skor dari tes awal ke tes akhir, dan terjadi peningkatan hasil belajar mahasiswa di kelas eksperimen sebesar 54,28\%.

Ada tidaknya perbedaan hasil belajar kognitif antara sebelum (pretes) dan setelah (postes) menggunakan komik dilakukan dengan t-tes untuk sampel dependen. Hasil pengujian menunjukkan bahwa nilai sig 0,000 yang berarti bahwa sig $<0,05$ maka $\mathrm{H}_{0}$ ditolak, yang berarti bahwa terdapat perbedaan hasil belajar kognitif yang signifikan antara sebelum (pretes) dan setelah (postes) menggunakan komik.

Berdasarkan Gain Score dan uji beda dapat disimpulkan bahwa media komik IPA memberikan dampak yang positif terhadap hasil belajar kognitif peserta didik yaitu terdapat perbedaan hasil belajar ranah kognitif antara sebelum dan setelah menggunakan komik di mana hasil belajar kognitif setelah menggunakan komik semakin baik. Dengan kata lain, media komik mampu meningkatkan hasil belajar ranah kognitif. Hal tersebut sesuai dengan penelitian yang dilakukan oleh Yasa dkk (2013) bahwa peserta didik yang belajar dengan menggunakan komik berorientasi kearifan lokal Bali lebih unggul dalam pemahaman konsep dibandingkan dengan peserta didik yang belajar tanpa menggunakan komik berorientasi kearifan lokal Bali. 
Jika ditinjau dari peningkatan motivasi dan peningkatan hasil belajar ranah kognitif, dapat disimpulkan bahwa peningkatan hasil belajar kognitif terjadi seiring dengan peningkatan motivasi belajar peserta didik. Hal tersebut menunjukkan bahwa motivasi memberikan dukungan terhadap hasil belajar peserta didik, sebagaimana dijelaskan oleh Yasa dkk (2013) bahwa peserta didik yang memiliki motivasi belajar tinggi akan lebih mudah mengikuti proses pembelajaran. Oleh karena itu, peningkatan motivasi, berpengaruh pula terhadap peningkatan aspek kognitif. Peserta didik yang dengan mudah dan antusias dalam mengikuti proses pembelajaran akan berdampak pada hasil belajarnya. Hal tersebut juga didukung oleh hasil penelitian Hamdu (2011) mengenai pengaruh motivasi belajar peserta didik terhadap prestasi belajar IPA menunjukkan bahwa motivasi belajar berpengaruh sebesar $48,1 \%$ terhadap prestasi belajar IPA. Penelitian Novianti (2011: 163) menunjukkan bahwa koefisien korelasi antara motivasi belajar siswa terhadap proses pembelajaran sebesar 0,614 .

\section{Hasil Belajar Afektif}

Instrumen yang digunakan untuk menilai hasil belajar afektif adalah lembar angket dan lembar observasi. Lembar angket (penilaian diri) diberikan kepada peserta didik dua kali, yakni sebelum dan setelah pembelajaran IPA menggunakan media komik sedangkan lembar observasi digunakan selama 6 tatap muka dengan menggunakan media komik.

Peningkatan hasil belajar afektif melalui angket dapat ditentukan dengan membandingkan data pengisian angket antara sebelum dan seteleh menggunakan media komik di dalam proses pembelajaran IPA. Peningkatan hasil belajar afektif belajar peserta didik diperoleh dengan cara mencari Gain Score. Hasil yang diperoleh menunjukkan bahwa peserta didik mengalami peningkatan hasil belajar afektif yang terlihat dengan besarnya nilai Gain Score yang diperoleh, yaitu sebesar 0,34 yang tergolong dalam kategori sedang.

Ada tidaknya perbedaan hasil belajar afektif antara sebelum dan setelah mengguna- kan komik dengan menggunakan data angket dilakukan dengan t-tes untuk sampel dependen. Hasil pengujian menunjukkan bahwa nilai sig 0,000 yang berarti bahwa sig $<0,05$ maka $\mathrm{H}_{0}$ ditolak, yang berarti bahwa terdapat perbedaan hasil belajar afektif yang signifikan antara sebelum dan setelah menggunakan komik.

Berdasarkan uji beda dan Gain Score menunjukkan bahwa terdapat perbedaan hasil belajar ranah afektif dan karakter peserta didik antara sebelum dan setelah menggunakan komik, di mana hasil belajar ranah afektif dan karakter setelah menggunakan komik menjadi lebih baik yang ditunjukkan dengan adanya peningkatan (Gain Score). Hal tersebut sesuai dengan penelitian mengenai model pembelajaran berbasis komik oleh Wahyudi (2007) diperoleh hasil bahwa pencapaian ranah afektif dalam pembelajaran pendidikan kewarganegaraan dengan penerapan model pembelajaran berbasis komik pada anak berkesulitan belajar sangat signifikan di Kabupaten Sidoarjo, Mojokerto, dan Kota Surabaya.

Hasil penilaian observasi afektif pada setiap pertemuan disajikan dalam Gambar 3.

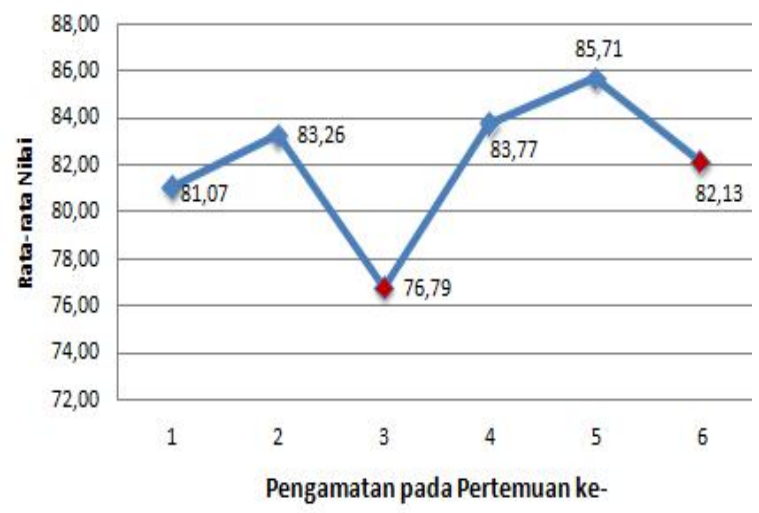

\section{Gambar 3. Rata-rata Penilaian Observasi Afektif pada Setiap Pertemuan}

Gambar 3 menunjukkan bahwa peningkatan motivasi belajar peserta didik terjadi pada pertemuan kedua, keempat, dan kelima. Pertemuan pertama, kedua, keempat, dan kelima diisi dengan aktivitas praktikum, sedangkan pertemuan ketiga dan keenam diisi dengan kegiatan tatap muka dan diskusi di dalam kelas. Pengamatan terhadap nilai sikap (afektif) pe- 
serta didik paling baik ketika pada aktivitas praktikum, khususnya pada nilai peduli lingkungan (kebersihan).

Hal tersebut disebabkan karena di dalam laboratorium terdapat tata tertib yang harus dipatuhi peserta didik, salah satunya yaitu untuk membuang sampah pada tempatnya. Sedangkan aktivitas pembelajaran di kelas jarang yang berada pada jam pertama sehingga kelas sudah tidak lagi bersih. Hal tersebut menunjukkan bahwa kesadaaran dan sikap peserta didik terhadap kepedulian lingkungan masih kurang.

Zuchdi (2011:22) bahwa pendidikan karakter dapat dilakukan menggunakan pendekatan komprehensif yang meliputi inkulkasi (penanaman), keteladanan, fasilitasi, dan pengembangan keterampilan. Penanaman pendidikan karakter dilakukan melalui ajakan dan pemodelan karakater yang baik di dalam cerita komik. Keteladanan tercermin dari watak dan aktivitas para tokoh dalam komik yang mengajak peserta didik untuk peduli terhadap lingkungan, bertanggung jawab, gemar membaca, dan besyukur atas ciptaan Tuhan. Fasilitasi dapat dilakukan dengan memberikan tat tertib dan aturan yang tegas atau memberikan hadiah atau hukuman, khususnya bagi peserta didik yang membuang sampah sembarangan. Melalui media komik IPA peserta didik secara tidak langsung difasilitasi untuk dapat memilah dan menerapkan karakter yang baik dan patut dicontoh di dalam kehidupan sehari-hari sehingga melalui pembelajaran dengan media komik dapat meningkatkan hasil belajar efektif.

\section{PENUTUP}

Berdasarkan hasil penelitian ini dapat disimpulkan bahwa media komik mampu meningkatkan motivasi, hasil belajar kognitif, dan hasil belajar afektif. Peningkatan motivasi dan hasil belajar afektif pada 6 pertemuan dengan media komik memberikan dampak yang positif jika aktivitas pembelajaran dilakukuan dengan menggunakan metode eksperimen dengan aktivitas laboratorium.

\section{UCAPAN TERIMA KASIH}

Ucapan terima kasih disampaikan kepada pendidik yang telah membantu hingga penelitian ini selesai. Ucapan terimakasih kepada peserta didik yang telah bersedia dengan antusias terlibat di dalam penelitian.

\section{DAFTAR PUSTAKA}

Arigiyati, Tri Astuti. 2011. "Pengaruh Kedisiplinan, Motivasi Belajar, dan Dukungan Orang tua terhadap Prestasi Belajar Mata Kulian Metode Statistika Mahasiswa Program Studi Pendidikan Matematika Angkatan 2009". Jurnal Wacana Akademika, Volume 3 No.9, halaman 922-93.

Daryanto. 2013. Media Pembelajaran. Yogyakarta: Gava Media.

Depdiknas. 2003. Undang-Undang RI Nomor 20, Tahun 2003 tentang Sistem Pendidikan Nasional. Jakarta: Depdiknas.

Depdiknas. 2005. Peraturan Pemerintah No.19 Th.2005. Jakarta: Depdiknas.

Hake, Richard R. 1998. "Interactive Engagement Versus Traditional Methods: A sixthousand-student Survey of Mechanics Test Data for Introductory Physics Course". Am. J. Phys. 66 (1), January, 1998. Diambil pada tangggal 10 Februari 2014 pukul 12:34 dari http://web.mit.edu/rsi/www/2005/misc/minipaper/paper s/Hake.pdf.

Hamdu, Ghullam \& Lisa Agustina. 2011. "Pengaruh Motivasi Belajar Siswa terhadap Prestasi Belajar IPA di Sekolah Dasar". Jurnal Penelitian Pendidikan. Vol. 12 No.1, halaman 81-86.

Kemdikbud. 2013. Kurikulum 2013, Kompetensi Dasar Sekolah Menengah Pertama (SMP)/Madrasah Tsanawiyah (MTs). 
Knight, Randall D. 2004. Five Easy Lessons. Strategy for Successful Physics Teaching. New York: Addison Wesley.

Mediawati, Elis. 2011. "Pembelajaran Akuntansi Keuangan melalui Media Komik untuk Meningkatkan Prestasi Mahasiswa". Jurnal Penelitian Pendidikan. Vol. 12 No. 1 April 2011.

Novianti, Nur Raina. 2011. "Kontribusi Pengelolaan Laboratorium dan Motivasi Belajar Siswa terhadap Efektifitas Proses Pembelajaran". Edisi Khusus No.1, Agustus 2011.

Nugraha, Eka Arif, Dwi Yulianti, \& Siti Khanafiyah. 2013. "Pembuatan Bahan Ajar Komik Sains Inkuiri Materi Benda untuk Mengembangkan Karakter Siswa Kelas IV SD”. Unnes Physics Education Journal. UPEJ 2, (1), halaman 60-68.

Sudjana, Nana \& Ahmad Rivai. 2011. Media Pengajaran. Bandung: CV Sinar Baru Algensindo.

Sulistyo, Joko. 2012. 6 Hari Jago SPSS 17. Yogyakarta: Cakrawala.

Suyanto, Slamet. 2011. Implementasi Pendidikan Karakter melalui Pembelajaran Terpa- du. Jurnal Cakrawala Pendidikan, Tahun XXX, No.3, halaman 97-109.

Wahyudi, Ari. 2010. "Model Pembelajaran Berbasis Komik untuk Mencapai Ranah Afektif pada Pendidikan Kewarganegaraan bagi Anak Berkesulitan Belajar". Jurnal Pendidikan dan Kebudayaan. Vol. 16 Edisi Khusus I. Juni 2010 halaman 43-52.

Wardani, Tri Kurnia. 2012. "Penggunaan Media Komik dalam Pembelajaran Sosiologi pada Pokok Bahasan Masyarakat Multikultural”. Jurnal Komunitas. Diambil pada tanggal 11 Juli 2013 pukul 09:33 dari http://journal.unnes.ac.id/sju/index.hp/komunitas.

Yasa, I Putu Wina, I Wayan Suastra \& I Made Candiasa. 2013. "Pengaruh Penggunaan Komik Berorientasi Kearifan Lokal Bali terhadap Motivasi Belajar dan Pemahaman Konsep Fisika". E-Journal Program Pascasarjana Universitas Pendidikan Ganesha, Volume 3 Tahun 2013.

Zuchdi, Darmiyati. 2011. Model Pendidikan Karakter Terintegrasi dalam Pembelajaran dan Pengembangan Kultur Sekolah. Yogyakarta: UNY Press. 